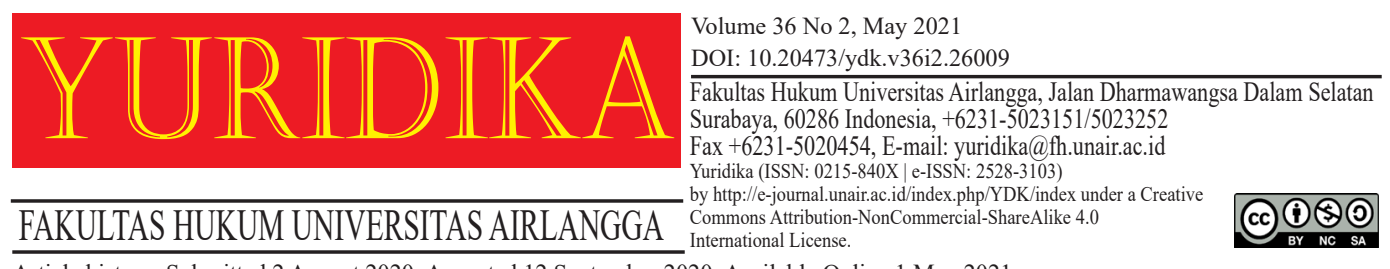

Article history: Submitted 2 August 2020; Accepted 12 September 2020; Available Online 1 May 2021.

\title{
Fairness in Fair Dealing on Industrial Design Protection
}

\author{
Sigit Nugroho, Derita Praptirahayu and Mieke Yustia Ayu Ratna Sari \\ snugroho571@gmail.com \\ Bangka Belitung University, Bangka Belitung University \\ and Tulang Bawang University
}

\begin{abstract}
Fair dealing is an important element in industrial design legislation. Analysing the concept of fair dealing can help society achieve fairness in protecting industrial design works. Fair dealing means that other parties can use industrial design for education and research purposes as long as it does not prejudice the interests of industrial design rights holders. This study aims to analyse the value of fairness in the concept of fair dealing in industrial design law to be used as guidelines for the rights holders and the public so they do not violate industrial design law and advance the welfare of society. This study uses normative legal research through statutes, conceptual approaches, and primary and secondary legal materials. This study finds that fairness in fair dealing and the protection of industrial design can be achieved by balancing the rights of designers and society. Fairness for both can be achieved if the rights holders and society have opportunities to use and enjoy industrial designs. Industrial design rights holders have limited monopoly rights, and the public can use the results of industrial design in a limited manner for their welfare. This is in line with Aristotle's observation that justice is given in accordance with values of propriety that are not the same.
\end{abstract}

Keywords: Fairness; Justice; Fair Dealing; Industrial Design Protection .

\section{Introduction}

Industrial designs are part of intellectual property rights (IPR) and have moral and economic rights. According to article 1 number 5 Law Number 31 of 2000 concerning Industrial Design (Law No 31/2000), industrial design rights are exclusive rights granted by the Republic of Indonesia to a designer for a certain period to carry out his own work or to consent to another party to exercise said rights. These rights include making, using, selling, importing, exporting and/or distributing goods granted industrial design rights. 
The exercise of exclusive rights over industrial designs created by the designer is accompanied by restrictions on rights or fair use (fair dealing). ' $F$ Fair dealing' allows the public to be able to take advantage of industrial designs for their interests without violating the rights of industrial design rights holders. 'Fair dealing' in Indonesia is more commonly known as 'the limitation of rights'. The civil law principle is 'the limitation of rights', while the common law principle is 'fair dealing'. ${ }^{2}$ Based on CHAPTER II (Scope of Industrial Design, Part Five Scope of Rights) article 9 paragraphs (1) and (2) of Law No 31/2000, the ownership of industrial design rights are as follows:

Article 9

(1) Holders of Industrial Design Rights have exclusive rights to exercise their Industrial Design Rights and to prohibit other people without their consent from making, using, selling, importing, exporting, and/or distributing goods granted Industrial Design Rights.

(2) Exempted from the provision as referred to in paragraph (1) is the use of Industrial Designs for research and educational purposes as long as it does not prejudice the reasonable interests of the holder of the Industrial Design rights.

Fair dealing in industrial designs is possible if it is in accordance with the objectives stipulated in the law. Therefore, if educational and research activities using industrial designs owned by designers are not based on the objectives referred to in the law, they may violate industrial design rights. Industrial design disputes indirectly indicate ignorance or lack of public understanding of the limitation of industrial design rights. The existence of industrial design lawsuits indicate problems in implementing the law.

It is possible for the public or other parties to use designs that have obtained industrial design rights in a study. The result of such research may be the development of a design that has similarities in several regards, such as shape, configuration, the composition of lines or colours, or a combination thereof that is three-dimensional

\footnotetext{
${ }^{1}$ Muhamad Djumhana and R Djubaedillah, Hak Milik Intelektual: Sejarah, Teori, Dan Praktiknya Di Indonesia (Citra Aditya Bakti 2014).[104].

${ }^{2}$ Rahmi Jened, Interface Hukum Kakayaan Intelektual Dan Hukum Persaingan (Penyalahgunaan HKI) (RajaGrafindo Persada 2013).[145].
} 
or two-dimensional. Such a scenario raises questions like the following:

- If this happens, does the research conducted by the community violate the rights of industrial design rights holders?

- Can the research results, in the form of design development from designs with industrial design rights, be registered by the party conducting the research and obtaining industrial design rights?

- Who should conduct the research to avoid violating the rights of industrial design rights holders?

- Is it not stated in the law that fair dealing can be carried out by parties other than industrial design rights holders, and the research referenced in Law No 31/2000 does not limit the purpose of research on industrial designs for which industrial design rights have been granted?

Given the lack of answers to these questions, an in-depth study of fair dealing or restrictions on the rights of industrial designs is necessary to avoid violations or illegal acts by other parties against rights holders. These restrictions can be used by other parties (who are also designers) to stimulate designers to create new designs to increase the competitiveness of the national industrial sector in the globalisation of trade and accelerate the development of national industries. This study examines fair dealing from the point of view of its use and industrial design users.

Given this background information, this study is concerned with two questions:

- (1) What is the concept of 'fair dealing' of industrial design?

- (2) What is justice in 'fair dealing' for industrial design rights holders and other parties?

This study of the concept of 'fair dealing' is limited to the scope of Law No 31/2000. This law is important as a basis to measure the use of industrial designs by rights holders or other parties fairly and in accordance with applicable regulations. It also limits the use of industrial designs by rights holders or the community, so there is no abuse of rights or illegal acts in Indonesia.

This study also adopts normative legal research with a discussion based on the prevailing laws and legal principles. ${ }^{3}$ It uses statute and conceptual approaches. The collection of legal materials is carried out by a literature study.

${ }^{3}$ ibid.[15]. 


\section{The Concept of Justice}

Justice comes from the root word 'just'. According to Indonesian Dictionary, the word 'just' means (1) equal weight, impartiality, not taking sides; (2) side with the right, hold on to the truth; and (3) properly, not arbitrarily. The word 'justice' means of a just nature (e.g. action, treatment). ${ }^{4}$

According to M Agus Santoso, the word 'fair' primarily means that a decision and action are based on objective norms, so they are neither subjective nor arbitrary. ${ }^{5}$ Justice for everyone is not the same; justice is given according to the merit that should be obtained for everyone through objective norms of measurement. Furthermore, Santoso stated that the scale of justice varies from place to place; each scale is defined and fully determined by the community in accordance with the public order. ${ }^{6}$ Thus, the measure of objective norms in justice is determined by the public order of the local community. In the context of Indonesia, the measure of objective norms in justice is determined by the noble values in the Indonesian people's view of life.

Jimly Asshiddiqie stated that justice is closely related to all notions of equal and equality, balanced and equilibrium, fair and fairness, and comparable and comparability. ${ }^{7}$ The many definitions related to justice indicate that justice has a close relationship with various areas of life. Muhammad Dhiaduddin Rais also expressed that justice has a general meaning and special meaning, including justice in 'muamalah', justice in law, justice in finance and justice in human rights. ${ }^{8}$

According to Asshiddiqie, justice is seen as a supreme virtue. ${ }^{9}$ Therefore, if realising justice for every dimension of life, it has manifested the highest virtue that will provide a balance for every dimension of life. Therefore, it is important to

\footnotetext{
${ }^{4}$ Kamus Besar Bahasa Indonesia (KBBI), 'Keadilan' < https://kbbi.web.id/keadilan> accessed 20 June 2020.

${ }^{5}$ M Agus Santoso, Hukum, Moral Dan Keadilan: Sebuah Kajian Filsafat Hukum (Kencana Prenada Media Group 2012).[85].

${ }^{6}$ ibid.

${ }^{7}$ Jimly Asshiddiqie, Konstitusi Keadilan Sosial (PT Kompas Media Nusantara 2018).[43].

${ }^{8}$ Fauzi Almubarok, 'Keadilan Dalam Perspektif Islam' (2018) 1 Jurnal ISTIGHNA.[115116].

${ }^{9}$ Asshiddiqie (n 7).[45].
} 
realise justice in all dimensions of everyday human life; in the end, what will emerge is virtue continuously, especially in various human relationships with others.

Many philosophers and jurists have proposed the concept of justice. However, in this study, the discussion of 'fair dealing' in industrial design protection uses Aristotle's proposed concept of justice and several other concepts of justice in accordance with his thought. Anton-Hermann Chroust and David L Osborn expressed their opinion of Aristotle's concept of justice. In principle, Aristotle's term 'just' has two separate meanings: (1) it is principally used to describe conduct in agreement with the 'law', ${ }^{10}$ and (2) justice signifies equality or a 'fair mean'. ${ }^{11}$

Justice or 'just', according to the first meaning in the sense of moral virtue, is determined by authoritative rules or rules of human behaviour. Justice or fair, according to the second meaning, is justice in the sense of proportional justice based on the principle of equality. ${ }^{12}$ Moral justice is justice in a broader sense, while equality is justice in a narrower sense. Moral justice is commonly referred to as legal justice, while justice in the sense of proportional justice based on the principle of equality has two forms: distributive justice (justitia distributiva) and commutative justice (justitia commutativa). Thomas Aquinas' views regarding justitia distributiva and justitia commutativa have followed Aristotle's views of justice. ${ }^{13}$

Legal justice (Iustitia Legalis) is justice according to legislation where the object is a society protected by legislation for the common good or banum commune. ${ }^{14}$ Regarding this legal justice, Aristotle wrote that 'the just, then, is the lawful and the fair, the unjust the unlawful and the unfair'. ${ }^{15}$ Furthermore, Aristotle observed the following:

\footnotetext{
${ }^{10}$ Anton-Hermann Chroust and David L Osborn, ‘Aristotle's Conception of Justice' (1942) 17 Notre Dame Law Review.[129-143].

${ }^{11}$ ibid.[130].

${ }^{12}$ ibid.[131].

${ }^{13}$ Otong Rosadi, Hukum, Ekologi Dan Keadilan Sosial Dalam Perenungan Pemikiran (Filsafat) Hukum (Thafa Media 2012).[86].

${ }^{14}$ Asshiddiqie (n 7). [57].

${ }^{15}$ Aristotle, Nicomachean Ethics (William David Ross tr, Batoche Books 1999).[72].
} 
Since the lawless man was seen to be unjust and the law-abiding man just, evidently all lawful acts are in a sense just acts; for the acts laid down by the legislative art are lawful, and each of these, we say, is just. Now the laws in their enactments on all subjects aim at the common advantage either of all or of the best or of those who hold power, or something of the sort; so that in one sense we call those acts just that tend to produce and preserve happiness and its components for the political society. ${ }^{16}$

Aquinas mentioned legal justice (justitia legalis) as concerning the whole law. Thus, it can be said that distributiva justitia and justitia commutativa are contained in legal justice. ${ }^{17}$ Otong Rosadi stated what is expressed by Meuwissen - that legal justice demands people are subject to all laws because the law was declared in the public interest. Because obeying the law is the same as being nice in everything, legal justice is also called general justice. ${ }^{18}$ It confirms what Chroust and Osborn suggested that

Justice is a virtue - the most difficult of all virtues - which differs from all other virtues in that it is displayed towards others and not towards oneself. It is the most perfect virtue because it is the practice of perfect virtue; it is a social virtue, for it involves a relationship with others, and embodies the good of others, because it does what is to the advantage of another. ${ }^{19}$

Furthermore, regarding Aristotle's second meaning of justice, the principle of equality is the basis of distributive justice and commutative justice, both of which are justice in the sense of proportional justice. As Chroust and Osborn explain

Equality, also called 'Justice in the narrow (or special) sense,' consists of two main phases, the first of which is exhibited in the act of 'distributing' certain matters between two or more persons, or in adjusting 'them to their proper ratios. Every form of proportional adjustment in the sense of Equality or 'equitable fairness' has to deal not only with the reciprocal claims of two or more persons, but also with the persons making the claims. The principle of Justice and Equality, which for the purpose of comparison always presupposes a duality, requires, therefore, at least four different factors: namely, two conflicting claims and two claiming persons should these two persons be of unequal rank they cannot be treated alike, for the principle of Equality demands that only equals be treated equally. In this sense Equality

\footnotetext{
${ }^{16}$ ibid. $[72-73]$.

${ }^{17}$ Rosadi (n 13).[86-87].

${ }^{18}$ ibid.[87].

${ }^{19}$ Chroust and Osborn (n 10).[134].
} 
is always proportionate equality - that is to say, it is a form of Justice which allots burdens according to the individual's ability to carry them and accords support in amounts which vary with the needs of the individuals - and is called 'distributive Justice.'

On the other hand, 'commutative Justice,' which constitutes the second phase of the principle of Equality or 'equitable fairness,' is distinguished from 'distributive Justice' in so far as it ignores the rank of the persons involved. Thus 'commutative Justice' requires only two factors, since its particular task is limited to the proportionate ratio between two 'goods' - labor and wage, damage and recovery, and the like. ${ }^{20}$

According to Chrous and Osborn's explanation, equality in Aristotle's concept of justice is also called justice in a narrow or special sense consisting of two main phases. The first phase distributes certain things between two or more people with a rights ratio. This is called distributive justice (justitia distributiva), a form of justice that divides the burden according to the individual's ability to carry it and provides support in varying amounts according to the individual's needs (proportional equality). So, according to Aristotle, the unjust violates the proportion. One term becomes too great, the other too small, as indeed happens in practice; for the man who acts unjustly has too much, and the man who is unjustly treated too little of what is good. ${ }^{21}$

Distributive justice (Iustitia Distributiva) is the treatment of a person according to the services he has done. ${ }^{22}$ Previously, Aristotle had suggested that 'this is plain from the fact that awards should be "according to merit"; for all men agree that what is just in distribution must be according to merit in some sense, though they do not all specify the same sort of merit...'.23

Meanwhile, the second phase differs from distributive justice insofar as it ignores the rank of the people involved; in other words, they do not see their achievements or services. This justice is called commutative justice. Commutative justice requires only two factors because duties are limited to the proportional ratio

\footnotetext{
${ }^{20}$ ibid. [135-136].

${ }^{21}$ Aristotle (n 15). [76].

${ }^{22}$ Asshiddiqie (n 7).[57].

${ }^{23}$ Aristotle (n 15).[76].
} 
between two goods, such as labor and wages or damage and recovery. Commutative justice is the payment of someone for services rendered to the community. ${ }^{24}$

Furthermore, Rosadi stated that:

Iustitia distributiva (distributive justice) stipulates that a proportional equation between human must be realized. This means that goods must be distributed to people (for example by the authorities) based on a certain criterion (work, achievement, need, or function). Meanwhile, Iustitia commutativa is exchange fairness, namely a balance in achievement and counter-achievement that must be manifested in civil relations (for example buying and selling, exchange, etc.). ${ }^{25}$

Regarding justice in the distribution of IPR, Rawls' theory of justice accords with the conditions of the current free-market era. His theory of justice can support Aristotle's concept of justice, which is intended to bring about justice in the current distribution of IPR.

Rawls suggested two principles of justice can be used as a reference in fulfilling justice in the distribution of IPR:

First: each person is to have an equal right to the most extensive scheme of equal basic liberties compatible with a similar scheme of liberties for others.

Second: social and economic inequalities are to be arranged so that they are both (a) reasonably expected to be to everyone's advantage, and (b) attached to positions and offices open to all. ${ }^{26}$

According to Rawls, the first principle of justice is that everyone has the same rights to the broadest basic freedom. The second principle is that social and economic inequality must be regulated in such a way so that (a) it can be expected to benefit everyone, and (b) all positions and offices are open to all. ${ }^{27}$

Rosadi stated that Rawls' theory of justice is important for two reasons. First, the procedure for achieving or seeking consensus places individuals in equal opportunities. Second, acknowledging the existence of inequality in society that must receive priority attention in the formulation or formation of laws and regulations. ${ }^{28}$ Furthermore, Rosadi

\footnotetext{
${ }^{24}$ Asshiddiqie (n 7).[57].

${ }^{25}$ Rosadi (n 13).[86].

${ }^{26}$ John Rawls, A Theory of Justice. Revised Edition (Harvard U Press 1999). [53].

${ }^{27}$ John Rawls and Kamdani, Teori Keadilan: Dasar-Dasar Filsafat Politik Untuk Mewujudkan Kesejahteraan Sosial Dalam Negara (Cet III, Pustaka Pelajar 2019).[72].

${ }^{28}$ Rosadi (n 13) 117.
} 
emphasised a valuable lesson that can be taken from Rawls's theory of justice, namely, the formation of laws must provide adequate protection for minority communities who have little access to resources in society. According to Rosadi, minority communities, poor communities or weak interest groups must be considered and become a consideration in decision-making when forming laws and regulations. ${ }^{29}$ Legislation must be drafted to protect everyone's interests according to their rights, especially to provide benefits or protection for the most disadvantaged communities.

Based on Rawls' theory of justice, Asshiddiqie wrote his opinion as follows:

The doctrine of social justice contains the main principle that (i) everyone is deemed to have the same right to obtain and enjoy the totality of the basic freedom system which is equal and applies equally to all people; and that (ii) inequalities, both social and economic, must be arranged so that they (a) provide the greatest benefit to the most disadvantaged citizens in living together and (b) provide equal opportunities to work and gain open positions on the terms of equal opportunity which is fair for all. ${ }^{30}$

The doctrine of social justice views everyone as having the same rights to basic freedoms that can be protected by law. Therefore, statutory regulations must be able to regulate gaps in the social and economic fields to bring about justice for citizens, especially the sharing of social benefits (rights) for every citizen.

Asshiddiqie suggests seven criteria to determine the extent to which the distribution of social benefits can be said to be fair, namely:

1. Distribution with equality (equal);

2. Distribution according to needs;

3. Distribution according to ability, merit, or achievements;

4. Distribution according to efforts and sacrifices;

5. Distribution according to actual productive contribution;

6. Distribution according to the requirements of common good, public interest, the welfare of mankind, or the greater good of a greater number;

7. Distribution according to the assessment of social services with the scarcity value between supply and demand based on the dynamics of market economic forces (according to a valuation of their socially useful services), namely based on market forces (according to market forces). ${ }^{31}$

\footnotetext{
${ }^{29}$ ibid. [117-118].

${ }^{30}$ Asshiddiqie (n 7).[92].

${ }^{31}$ ibid.[93].
} 
Regulating the distribution of IPR produced by a person can be based on Aristotle's theory that such distribution must be in accordance with their achievements. The State gives this right to someone who has produced an intellectual creation manifested in a tangible way that can be useful or used by the community to achieve a better or prosperous life.

The appreciation for one's achievements in producing intellectual creations can be given by the state fairly based on Asshiddiqie's seven criteria, either accumulatively or not. For example, with regard to fair dealing, the protection of industrial designs as an IPR is granted by the state to designers based on the criteria 'Distribution according to ability, merit, or achievements' or 'Distribution according to effort and sacrifices.' The granting of exclusive rights by the State to designers for the intellectual work they produce can be considered fair because the designer has exerted all of his abilities, efforts and sacrifices through the energy, time and cost spent to produce a design to achieve economic prosperity and existence of self.

\section{Industrial Design Elements}

IPR can be defined as a right to property that arises or is born due to human intellectual abilities. ${ }^{32}$ Budi Agus Riswandi and Shabi Mahmashani observe that the results of human thinking that are manifested in a real can produce a work known as intellectual property. ${ }^{33}$ According to Khoirul Hidayah, IPRs are economic rights granted by law to a creator or inventor for a work from human intellectual abilities. ${ }^{34}$

IPR is conceptually a legal right given to the results of intellectual creations (intellectual property) that have been manifested. This legal right gives rise to a monopoly right in the form of the right to use, the right to give permission and transfer these rights to other people, and the right to prohibit other people from

\footnotetext{
${ }^{32}$ Budi Santoso, Butir-Butir Berserakan Tentang Hak Atas Kekayaan Intelektual (Desain Industri) (Mandar Maju 2005).[53].

${ }^{33}$ Budi Agus Riswandi and Shabhi Mahmashani, Dinamika Hak Kekayaan Intelektual Dalam Masyarakat Kreatif (Total Media 2009).[30].

${ }^{34}$ Khoirul Hidayah, Hukum Hak Kekayaan Intelektual (Setara Press 2017).[1].
} 
exercising these rights. ${ }^{35}$ This monopoly right is obtained because these intellectual works, whether in science, art, literature or technology, were born at the expense of energy, time and even money. These sacrifices make the resulting work valuable. When added with the economic benefits that can be enjoyed, the inherent economic value gives rise to the conception of wealth (property) for these intellectual works. ${ }^{36}$

IPR branches generally refer to Trade-Related Aspects of Intellectual Property Rights (TRIPs). According to TRIPs, there are seven main elements of protection: copyrights and related rights, trademarks, geographical indicators, industrial designs, patents, design of integrated circuits and protection of undisclosed information.

Broadly speaking, IPR as a legal right can be divided into two parts: copyright and industrial property rights. One of the industrial property rights is industrial design. The design of a product has been around since at least 2800 BC. Regulatory and legal aspects regarding design, especially those concerning industrial design, were only known in the 18th century. ${ }^{37}$ The creation of a work or other people who work resulting in intellectual ability is considered reasonable if they receive a reward for their work. Rewards can be material or immaterial. The law protects the work in the interests of the creator, which can be called rights. Every right according to law has a title, which is a certain event that becomes the reason for the inherent rights of the owner. With regard to IPRs, the event that is the reason for it is a creation based on intellectual abilities. ${ }^{38}$ For example, someone produces a work in the form of a beautiful design on an industrial product. That person has ownership rights to the design and is also entitled to a reward for his work.

According to Achmad Zen Umar Purba, industrial design is an intellectual work that produces a product that has a special character in a formal or ornamental appearance, which creates an aesthetic impression and is mass-produced. ${ }^{39}$ Protection of the right to industrial design is part of the jurisdiction of a country.

\footnotetext{
35 ibid.

${ }^{36}$ Santoso (n 32). [54].

${ }^{37}$ Djumhana and Djubaedillah (n 1).[285].

${ }^{38}$ ibid.

${ }^{39}$ Achmad Zen Umar Purba, Hak Kekayaan Intelektual Pasca TRIPs (Alumni 2011).[77-78].
} 
The state has the right to regulate individual rights that are not solely a domestic issue because protecting the right to industrial design is a transnational interest. One aspect of State sovereignty is the external aspect, meaning the highest power to establish relations with members of the international community and regulate everything that occurs outside the territory of that State as long as it is related to the interests of that State. However limited by law. ${ }^{40}$

Industrial design protection is regulated in several international treaties. The Paris Convention for the Protection of Industrial Property (Paris Convention) stipulates that the protection of industrial designs is only regulated by one article article 5quinquies provides that 'Industrial designs shall be protected in all countries of the Union'. The Paris Convention stipulates that industrial designs will be protected in all member countries. Furthermore, article 25 of TRIPs stipulates that

Members shall provide for the protection of independently created industrial designs that are new or original. Members may provide that designs are not new or original if they do not significantly differ from known designs or combinations of known design features. Members may provide that such protection shall not extend to designs dictated essentially by technical or functional considerations. Each Member shall ensure that requirements for securing protection for textile designs, in particular in regard to any cost, examination or publication, do not unreasonably impair the opportunity to seek and obtain such protection. Members shall be free to meet this obligation through industrial design law or through copyright law.

TRIPs provides flexibility to member countries to protect independently created industrial designs that are new or original. Member countries may provide that such protection would not include a design that is essentially determined by technical or functional considerations. Each member country must ensure the requirements for securing the protection of textile designs. Each country can regulate industrial designs through industrial design laws or copyright laws. ${ }^{41}$

Rahmi Jened Parinduri Nasution ${ }^{42}$ said there are some design elements in the protection scope:

\footnotetext{
${ }^{40}$ I Wayan Parhiana, Pengantar Hukum Internasional (Mandar Maju 1990).[294-295].

${ }^{41}$ Jened (n 2).[254].

${ }^{42}$ ibid. [255].
} 
1. Creations about shapes, configurations or patterns;

2. The new look is aesthetically appealing;

3. Applied to goods that are mass produced (mass product).

Nasution stated that protection is given to design features that are visible (visual appearance) and are applied to an item (article) and not the item itself. ${ }^{43}$ The appearance of a beautiful design does not have to be such noble beauty like fine art, but practically, the design gives the user or owner an item to enjoy his life, a feeling of pleasure, freshness, comfort and so on. In Indonesia, it is the law that a registered design must be a new design, meaning it must be compared to existing designs. The design to be registered (protected) must not be known or used within six months prior to the filing date of registration. ${ }^{44}$ The design can be used to produce a product, goods, industrial commodity or handicraft that is mass-produced.

Design requirements that can be protected are new or original. The new design requirements are close to the patent requirements, namely novelty. A design is considered new if it has a special appearance different from the prior art. ${ }^{45}$ Acquisition of industrial design rights in Indonesia is based on the first to file rule, meaning that industrial design rights are granted through registration and for new designs. ${ }^{46}$

The period of protection given to industrial designs follows article 26 (3) of TRIPs, which stipulates that 'The duration of protection available shall amount to at least 10 years.' Article 5 paragraph (1) of Law No 31/2000 similarly stipulates that 'Protection of Industrial Design Rights is granted for a period of 10 (ten) years from the Filing Date.'

Designers or parties who register industrial designs will get industrial design rights, which have certain rights. According to article 26 (1) of TRIPs, the rights of industrial design rights holders are as follows:

\footnotetext{
${ }^{43}$ ibid. [256].

${ }^{44}$ ibid. [256-257].

${ }^{45}$ ibid. Perlindungan Hukum Desain Industri. Makalah yang disampaikan pada Pelatihan Hak Atas Kekayaan Intelektual (HAKI) VI Bagi Para Dosen Perguruan Tinggi Wilayah Indonesia Timur yang diseleggarakan oleh Fakultas Hukum Universitas Airlangga bekerjasama dengan Indonesia Intellectual Property Society (IIPS), Surabaya, 27 Agustus sampai dengan September 2001, 7.

${ }^{46}$ ibid.[260].
} 
The owner of a protected industrial design shall have the right to prevent third parties not having the owner's consent from making, selling or importing articles bearing or embodying a design which is a copy, or substantially a copy, of the protected design, when such acts are undertaken for commercial purposes.

The provisions in the TRIPs are reflected in article 1 number 5 and article 9 of Law No 31/2000, which read as follows:

Industrial design is a creation concerning the shape, configuration, or composition of lines or colors, or lines and colors, or a combination thereof in three or two-dimensional forms that give an aesthetic impression and can be realized in three-dimensional or two-dimensional patterns and can be used to produce a product, goods, industrial commodity, or handicraft.

The holder of industrial design rights has the exclusive right to exercise his industrial design rights and to prohibit other people without their consent from making, using, selling, importing, exporting and/or distributing goods that are granted industrial design rights.

Meanwhile, the limitation of the exclusive rights under article 26 (2) TRIPs stipulates:

Members may provide limited exceptions to the protection of industrial designs, provided that such exceptions do not unreasonably conflict with the normal exploitation of protected industrial designs and do not unreasonably prejudice the legitimate interests of the owner of the protected design, taking account of the legitimate interests of third parties.

The limitation given to industrial design rights concerns the exception in article 4 of Law No 31/2000 that industrial design rights cannot be granted if the industrial design is contrary to the prevailing laws and regulations, public order, religion or morals. Therefore, as long as it does not harm the reasonable interests of the holders of industrial design rights, the use of industrial designs for research and education purposes is not considered a violation of article 9 paragraph (2) of Law No $31 / 2000$.

\section{Fair Dealing Concept in Industrial Design}

The concept of fair dealing or fair use is widely known in copyright protection. Fair dealing is commonly used in the UK and countries with commonwealth and civil law jurisdictions. Fair use is used by the United States. The term fair dealing is 
similar to fair use. According to Sanusi Bintang, fair dealing or fair use is generally applied by many countries that allow the multiplication of creation but do not qualify as copyright infringement. ${ }^{47}$

The fair dealing doctrine was first used in France and Germany before being included in the Berne Convention for the Protection of Literary and Artistic Works in $1928 .{ }^{48}$ In the UK, 'fair dealing' is based on moral rights. Moral rights are an author's rights over the work of his creation, and the term is generally used in civil law countries. ${ }^{49}$ Diyah Ratnajati stated that the purpose of moral rights is to protect the personality or reputation of the creator and copyright holder of copyrighted works. ${ }^{50}$ According to the literature, the meaning of fair dealing includes the following:

Fair dealing is a user's right in copyright law permitting use of, or 'dealing' with, a copyright protected work without permission or payment of copyright royalties. The fair dealing exception in the Copyright Act allows you to use other people's copyright protected material for the purpose of research, private study, education, satire, parody, criticism, review or news reporting, provided that what you do with the work is 'fair'. If your purpose is criticism, review or news reporting, you must also mention the source and author of the work for it to be fair dealing. ${ }^{51}$

Another definition of fair dealing is a limitation and exception to the exclusive right granted by copyright law to the author of a creative work. ${ }^{52}$ From these two definitions, one can see that the concept of fair dealing is widely used in copyright protection. This protection is given in relation to the use of copyright by other parties (not the holder of exclusive rights over IPRs).

\footnotetext{
${ }^{47}$ Sanusi Bintang, Hukum Hak Cipta (Citra Aditya Bakti 1998) 49; Anis Mashdurohatun and M Ali Mansyur, 'Identifikasi Fair Dealing/Fair Use Hak Cipta Atas Buku Dalam Pengembangan IPTEK Pada Pendidikan Tinggi Di Jawa Tengah’ (2015) 4 Yustisia 522, $523<$ https://doi.org/10.20961/ yustisia.v4i3.8682>.

${ }^{48}$ Diyah Ratnajati, 'Perbandingan Doktrin Fair Use Pada Internet Antara Amerika Serikat Dan Indonesia' (Program Megister Ilmu Hukum, Program Pascasarjana, Universitas Diponegoro, Semarang 2008).[13].

49 ibid.

${ }^{50} \mathrm{ibid}$.

${ }^{51}$ Simon Fraser University, 'What Is Fair Dealing and How Does It Relate to Copyright?' $<$ www.lib.sfu.ca/help/academic-integrity/copyright/fair-dealing> accessed 20 December 2020.

${ }^{52}$ Wikipedia, 'Fair Dealing' <https://en.wikipedia.org/wiki/Fair_dealing> accessed 20 December 2020.
} 
Industrial design also applies the concept of fair dealing. However, this concept is an exception and not the rule. Rahmi Jened revealed related cases with the following exceptions:

The protection practices of Industrial Design in Europe and America have repairs clause given based on lobbying from the spare parts manufacturing industry. Repair clause contains a rule that the actions of manufacturers and spare parts manufacturers for the purpose of repairing complex products (cars) must be permitted without violating Industrial Design Rights, such as repairing car windows, if complete and adequate information has been provided to consumers. ${ }^{53}$

Fair dealing in industrial designs in Indonesia is based more on restrictions on exclusive rights (from the point of view of rights holders) and the use of industrial designs by other parties (fair use) in research and education.

In Indonesia, the regulation of restrictions or fair dealing by non-exclusive rights holders or the public on industrial designs can be seen in article 9 paragraphs (1) and (2) of Law No 31/2000. Ownership of copyrighted works does not necessarily make a person monopolise and enrich themselves from the economic rights they have obtained. ${ }^{54}$ To balance the owner's rights with the community's interests, it is necessary to have fair dealing for the community. 'Fair dealing' in industrial designs appears in article 9 paragraphs (1) and (2) of Law No 31/2000, which stipulate the following:

Article 9

(1) The holder of industrial design rights has the exclusive right to exercise his industrial design rights and to prohibit other people without their consent from making, using, selling, importing, exporting and / or distributing goods that are granted industrial design rights.

(2) Exempted from the provisions referred to in paragraph (1) is the use of Industrial Designs for research and education purposes as long as it does not harm the reasonable interests of the holder of the Industrial Design rights.

\footnotetext{
${ }^{53}$ Jened (n 2).[262].

${ }^{54}$ Khoirul Hidayah, Hukum HKI Di Indonesia: Kajian Undang-Undang Dan Integrasi Islam
} (UIN-Maliki Press 2012).[48]. 
The Elucidation of article 9 of Law No 31/2000 provides that 'use' is meant here only for research and education purposes, including research and development testing. However, such use may not be detrimental to the reasonable interests of the designer, whereas what is meant by 'reasonable interests' is the use for educational and research purposes, generally not included in the use of the right to an industrial design as referred to in paragraph (1). In education, for example, the 'reasonable interests' of the designer will be harmed if the industrial design is used for all educational institutions in that city. The criterion of importance is measured not only by the presence or absence of commercial elements but also by the quantity of use. As stated by Ratnajati, the doctrine of fair dealing in the UK cannot be applied to matters outside education, research, knowledge enhancement and information dissemination. ${ }^{55}$ Fair dealing in industrial designs is implicitly emphasised in the protection of moral rights, whether for the interests of exclusive rights holders or the use of limited industrial designs by other parties. However, for 'reasonable interests', the main objective is to protect economic rights for exclusive rights holders. The phrase 'reasonable interests' comes from article 9 above.

\section{Justice in Fair Dealing on Industrial Design}

The concept of fair dealing in copyright protection can be found in industrial designs and is contained in article 9 of Law No 31/2000. According to article 9 paragraph (2), the use of industrial designs for research and education purposes is not allowed unless such use does not harm the reasonable interests of the holder of the industrial design right. This can be seen in the article, which reads '... as long as it does not harm the reasonable interests of the holder of the Industrial Design right'. So, the use of industrial designs for research and education purposes is still permissible as long as it does not harm reasonable interests in terms of making, using, selling, importing, exporting and/or distributing goods granted industrial design rights. However, such use must not be detrimental to the reasonable interests

\footnotetext{
${ }^{55}$ Ratnajati (n 49).[14].
} 
of the designer. According to the Elucidation of Article 9 of Law No 31/2000, 'reasonable interest' (fair dealing) is:

'Reasonable interest' is the use for educational and research purposes, in general, it is not included in the use of Industrial Design rights as referred to in paragraph (1). In the field of education, for example, the reasonable interest of the designer will be harmed if the Industrial Design is used for all educational institutions in that city. The criterion of importance is not only measured by the presence or absence of commercial elements, but also by the quantity of use.

The explanation still leaves open three problems. First, a reasonable quantity or amount of use of industrial designs for research and education purposes is permitted. Second, legal subjects or whoever gets the exemptions referenced in article 9 paragraph (2) of Law No 31/2000. Third, granting exclusive rights to research results (including research and development tests) in accordance with the research results as referenced in article 9 paragraph (2).

Before entering into 'justice in fair dealing on industrial design', we first discuss the three problems above. First, the quantity or fair amount of permitted use of industrial designs for research and education purposes. Law No 31/2000 does not specify how much or what quantity of use of an industrial design for research and education purposes is permitted. In Law No 31/2000, only examples are given in education. For example, the reasonable interest of the designer would be harmed if the industrial design was used for all educational institutions in the city. There is no further explanation of how many quantities can be used to determine that the use of the industrial design includes fair use.

Article 9 paragraph (2) of Law No 31/2000 stipulates that ' $\ldots$ as long as it does not harm the reasonable interests of the holder of Industrial Design rights.' When linked with the explanation of article 9 paragraph (2), several points can be concluded to determine fair use in industrial designs, namely:

1. The criterion of importance is measured not only by the presence or absence of commercial elements but also by the quantity of use.

2. The quantity or the amount used cannot be clearly determined. The lack of clarity over quantity allows judges to interpret and rationalise cases or disputes in the context of a fair legal discovery.

3. The number of uses of industrial designs can be said to be detrimental to the 
owner of the industrial design rights if it can be proven that the use of industrial designs has violated article 9 paragraph (1) of Law No 31/2000, meaning if another party (not the owner of the industrial design rights) has committed the act of making, using, selling, importing, exporting and/or circulating goods that are granted industrial design rights, without the approval of the owner of the industrial design rights. The use of industrial designs in quantity can be proven to have caused real losses for the owners of industrial design rights.

Second, regarding legal subjects or whoever gets the exemptions mentioned in article 9 paragraph (2) of Law No 31/2000. The first owner of the design is usually the creator (designer) unless there are special conditions. ${ }^{56}$ The subject of industrial design under articles $6-8$ is as follows.

\section{Article 6}

(1)Those entitled to obtain industrial design rights are designers or those who receive said rights from the designer.

(2)In the event that a designer consists of several people jointly, the right to industrial design is given to them jointly, unless agreed otherwise.

\section{Article 7}

(1)If the industrial design is created in official relation with other parties in the official environment, the authority of industrial design rights is the party where the design created, unless there is another agreement between two parties without ignoring the creator rights if the use of industrial design is expanded outside official relation.

(2) The provisions as referred to in paragraph (1) shall also apply to Industrial Designs made by other people based on orders made in an official relationship.

(3) If an Industrial Design is made in a working relationship or based on an order, the person making the Industrial Design is deemed to be a Designer and Right Holder to Industrial Design, unless agreed otherwise between the two parties.

\section{Article 8}

The provisions as referred to in Article 7 paragraph (1) and paragraph (2) do not remove the designer's right to have his name listed on the Industrial Design Certificate, General Register of Industrial Designs and the Official Gazette of Industrial Designs.

Article 6 of Law No 31/2000 stipulates that those entitled to obtain industrial design rights are designers or those who receive these rights from designers. The designer can be one person or several people. Another party who receives industrial

\footnotetext{
${ }^{56}$ Hidayah (n 34).[141].
} 
design rights is a party granted Industrial Design rights by a designer or a previous Industrial Design Right Holder by transferring Industrial Design rights through inheritance, grants, wills, written agreements, or other causes justified by statutory regulations (article 31 paragraph (1) of Law No 31/2000).

Article 9 paragraph (2) of Law No 31/2000 does not further elaborate on who can use the industrial design in the context of exempted usage. Anyone is allowed to use the industrial design for research and education purposes, including testing research and development. The fair use of this industrial design (exceptions in use of the design in article 9 paragraph (2)) provides the widest possible opportunity for other parties to be able to research and develop an existing design (which has attached an exclusive right to the design) so that other parties can create (design) a new industrial design that has a distinguishing power or can be similar to the existing industrial design. That way, industrial designs resulting from research (including research and development tests) carried out by other parties (whoever) are allowed. Other parties who are allowed to do so can be in the form of legal entities, non-legal entities, agencies that are part of the government, private agencies, persons, groups of people (associations) and so on.

Third, suppose the design of the research results is allowed. In that case, the next question is whether the design of the results of the research (including research and development tests) carried out by other parties can be given exclusive rights if they meet the novelty element?

The element of novelty, which is the basis for registration of industrial designs, is stipulated in articles 2 and 3 of Law No 31/2000 as follows.

\section{Article 2}

(1) Industrial Design Rights are granted for new Industrial Designs.

(2) An Industrial Design is considered new if on the Filing Date, the Industrial Design is not the same as the existing disclosures.

(3)Previous disclosures as referred to in paragraph (2) are disclosures of Industrial Designs which before:

a. receipt date; or

b.priority date if the application is filed with a priority right; has been announced or used in Indonesia or outside Indonesia. 


\section{Article 3}

An Industrial Design is not deemed to have been announced if within a period of 6 (six) months before the Filing Date, the Industrial Design:

a. has been shown in a national or international exhibition in Indonesia or abroad which is official or recognized as official; or

b. has been used in Indonesia by the designer in the framework of an experiment for the purpose of education, research or development.

The article above explains that an industrial design can be registered if it meets the element of novelty. Furthermore, article 6 paragraphs (1) and (2) of Law No 31/2000 stipulate that 'those entitled to obtain Industrial Design Rights are designers or those who receive such rights from designers', and, 'in the case that the designer consists of several people together, the right to industrial design is given to them collectively, unless agreed otherwise.' Article 1 point (2) states that 'a designer is a person or several people who produce an industrial design.' According to article 1 point (2), a designer is anyone who can do or produce industrial designs, and a designer can be one person or several people. Moreover, a person includes a legal or non-legal entity. From this description, it can be concluded that if a person or several people who can produce industrial designs has met the novelty element, then the resulting designs (including the results of research in which there are research and development tests) can be registered, and the designer is entitled to industrial design rights from the results of the research he has done.

The use of industrial designs without the permission of industrial design rights holders is allowed provided that the use of industrial designs is carried out within the framework of research and education; the research and education that has been carried out has not been detrimental to the owner of industrial design rights in real, which means that the loss must be proven first; the legal subject who conducts research may also be any person or a party other than the holder of industrial design rights who is an individual, legal entity or non-legal entity; and design results from research can be registered and entitled to exclusive rights if they meet the element of novelty.

Indonesia was originally a developing country and considered IPRs to be new. Law No 31/2000 was intended to advance the industrial sector by increasing 
competitiveness and utilising the role of industrial design, as stated in the general section on the explanation of Law No 31/2000 as follows:

Indonesia as a developing country needs to advance the industrial sector by increasing competitiveness. One of these competitiveness is to take advantage of the role of Industrial Design which is part of Intellectual Property Rights. Cultural diversity combined with efforts to participate in the globalization of trade, by providing legal protection for industrial designs will accelerate the development of national industries.

Furthermore, the explanation states that:

The legal protection given to Industrial Design Rights is intended to stimulate creative activities of designers to continually create new designs. In the context of creating a climate capable of encouraging the spirit of the creation of new designs and at the same time providing legal protection, the provisions of Industrial Designs are compiled in this Law. Protection of Industrial Design Rights is granted by the Republic of Indonesia if requested through a registration procedure by a designer, or a legal entity entitled to such Industrial Design Rights.

To balance the rights of rights holders and society, it is necessary to develop the role of regulating industrial design in accordance with the goals of legal ideals (rechtsidee) based on State ideology, namely Pancasila, one of which is social justice for all Indonesian people. According to Muhammad Hoiru Nail and Made Arya Utama, the formation of legislation to be made and implemented in Indonesia is inseparable from the nuances of Pancasila. ${ }^{57}$ The principles of Pancasila will be used as guidelines in legal behaviour for the community. This legal behaviour built with the spirit of the nation's soul (volkgeist) will provide direction and progress in legal development that society aspires to so that law becomes the only spirit of society in carrying out all its activities because it departs from the soul of the community. ${ }^{58}$ Thus, the goals of legal ideals can be realised well in Indonesia.

\footnotetext{
${ }^{57}$ Muhammad Hoiru Nail and Made Arya Utama, 'Pancasila and Religious Values in Establishment of Legal Regulations’ (2020) 9 Jurnal Magister Hukum Udayana $297<$ https://ojs.unud. ac.id/index.php/jmhu/article/view/ 58781>.

${ }^{58}$ La Ode Dedihasriadi and Edy Nurcahyo, 'Pancasila Sebagai Volkgeist: Pedoman Penegak Hukum Dalam Mewujudkan Integritas Diri Dan Keadilan’ (2020) 9 Jurnal Magister Hukum Udayana $148<$ https://doi.org/10.24843/JMHU.2020.v09.i01.p10>.
} 
The supreme goal of law is justice. ${ }^{59}$ A sense of justice must be enforced in every line of human life related to legal issues because the law requires the realisation of justice. ${ }^{60}$ Therefore, all efforts related to absolute law must be directed to find the most suitable legal system in accordance with the principle of justice. ${ }^{61}$ Fair dealing contained in industrial design law is designed to fulfil a sense of justice for the public, meaning that fair dealing contained in industrial designs has met the constitutive elements of all definitions of law. Huijber and Muhammad Syukri Albani Nasution and others ${ }^{62}$ have stated that fair is a constitutive element of all definitions of law.

As described earlier, in principle, the justice proposed by Aristotle requires proportional equality, one of which is in terms of distributing certain things between two or more people with the right ratio. The award must be in accordance with the achievement to make it fair. Therefore, regulating industrial design rights requires the distribution of rights proportionally in accordance with the services.

Based on the description of fair dealing in industrial design arrangements above. It can be said that the granting of rights to industrial design rights holders (designers) and granting rights to the public to take advantage of the industrial design rights of the holders contains the principle of proportionality, each (right holder and society) can use the right to a design fairly in accordance with services or achievements (role). In addition, fair dealing has met the principle of proportional equality or equal rights (equal opportunities) in obtaining rights to utilise intellectual property.

According to Rawls, the existence of inequality or inequality (rights holders and society) in obtaining resources, especially intellectual property, has been regulated in such a way by law (in this case Law No 31/2000) so that the community as parties those who are less fortunate in enjoying economic rights to

\footnotetext{
${ }_{59}$ Muhammad Syukri Albani Nasution and others, Hukum Dalam Pendekatan Filsafat (Kencana 2016).[214].

${ }^{60}$ ibid. [213].

${ }^{61}$ ibid.[214].

62 ibid.
} 
intellectual property resources may benefit as well. Given that the industrial design rights holder is the party who owns the business, sacrifice, ability or achievement, the rights holder is entitled to the industrial design he produces to be used according to his wishes with limitation or restricted by law (article 28J paragraph (2) of the 1945 Constitution).

Meanwhile, the community is a party that does not have a role in producing the industrial design. However, to maintain the balance of rights and social functions of property rights mandated by the values of Pancasila, the community is allowed to use it for the purposes of education and research fairly as long as it does not harm the rights of the industrial design rights holders. Thus, the practice of social virtue (social justice) can be realised. This is in accordance with the ideals of Indonesian law, namely, social justice for all Indonesian people. Thus, as stated by Koerniatmanto Soetoprawiro, Rawls' concept of social justice is not only that all the same or equal freedoms of each person are protected only but also that basic freedoms are effectively carried out by all parties in society who are concerned to the degree that the comfortable atmosphere of freedom feels the maximum for the worst off (those who are less fortunate). ${ }^{63}$

Fair dealing in Law No 31/2000 provides regulation by distributing rights and obligations equally in society so that everyone has the opportunity to benefit from it and bears the same burden. ${ }^{64}$ The industrial design regulation thus is in accordance with the objective of its legal protection, which is intended to stimulate designers to continuously create new designs, because everyone has the opportunity to be a designer.

Based on the above, according to the theory presented by Aristotle and Rawls, fair dealing in industrial design is given to balance the rights between the industrial design rights holders and other parties (the public) in accordance with the fairness it conveys. Rights obtained by holders of industrial design rights and society in

\footnotetext{
${ }^{63}$ Koerniatmanto Soetoprawiro, 'Keadilan Sebagai Keadilan (Justice as Fairness)' (2010) 28 Jurnal Hukum Pro Justitia $232<$ https://journal.unpar.ac.id/index.php/projustitia/article/view/1064>. ${ }^{64}$ ibid. [237].
} 
accordance with their respective accomplishments. Holders of industrial design rights (exclusive rights) have the right to monopolise the designs of their work with certain limitations, namely, not to violate the prevailing laws and regulations, public order, religion or morals. For the sake of fairness, the exclusive right to monopolise industrial designs is restricted, and there is freedom for the community (other parties) to be able to use these designs only for educational and research purposes. The community (all circles) can utilise these designs for educational and research activities to be able to spur people's creative ideas to improve community welfare by producing new designs and obtaining economic and moral benefits. Fair use rights in industrial designs that already have these rights reflect fairness on the distribution of rights (benefits) for the most disadvantaged citizens or communities (do not have IPRs and cannot enjoy moral and economic rights over these rights).

Fair dealing in industrial designs has provided a sense of justice for the community because, in the principle of fair dealing, there is a community's right to the work of others which can be used to improve their welfare in all respects. Justice, according to Aristotle and Rawls, who believes that justice that guarantees the interests of all parties (public interest) fairly is contractual justice in accordance with the values contained in Pancasila (which is the nation's political consensus), namely the value of social justice for all Indonesian people.

As a developing country, Indonesia must be able to compete with other countries and prosper its people by always adhering to the values of Pancasila. The fifth postulate, 'Every law must improve the welfare of society', means that every law discussed by the House of Representatives with the joint approval of the president must: ${ }^{65}$

1. Create community welfare.

Every law is not detrimental to the public interest and must prosper the community in all aspects of life.

2. Avoid interests that harm the community

${ }^{65}$ Backy Krisnayuda, Pancasila Dan Undang-Undang (Kencana Prenada 2017).[250]. 
Laws based on collective agreement must prioritise the community's interests over the interests of certain groups.

The concept of fair dealing is a manifestation of the value of social justice embodied in the legislation on industrial design, namely Law No 31/2000. This law has guaranteed the value of fairness in the use of industrial designs for designers and the public. It is in accordance with what Candra Irawan conveyed regarding the principles used as the basis for political law and regulation of IPRs in Indonesia, including the principle of human benefit, the principle of humanity, and the principle of balancing the interests of individuals and society. That way, more people will feel the goodness and benefits of industrial design by maintaining a fair balance of rights between designers and society (other parties).

\section{Conclusion}

The concept of fair dealing in industrial designs is that other parties can use industrial designs for educational and research purposes. Fair dealing of industrial designs can be justified as long as it does not harm the economic and moral interests of the industrial design rights holder.

Fair dealing in industrial designs is embodied in article 9 paragraph (2) of Law No 31/2000. The concept of fair dealing is realised to fulfil the values of justice contained in Pancasila. This is evidenced by allowing the Indonesian people to properly use existing industrial designs for which the rights of the holders are still attached to the industrial design. Doing so provides opportunities for the public to spur their creative ideas in producing new designs that they can use for their own welfare to ensure that the rights of industrial design holders remain well protected. Thus, the award for intellectual work (industrial design) is based on individual achievements, as expressed by Aristotle. Designers are given more rights over their achievements, namely monopolising the industrial designs they produce in a limited way, while the public is still given the right to use these industrial designs as long as they do not harm the reasonable interests of the designer. In other words, fairness in a fair transaction and the protection of industrial designs can be achieved by 
balancing the rights of designers and society. Industrial design rights holders have limited monopoly rights, and the public has the opportunity to use limited industrial designs for their welfare. This is all in accordance with Aristotle's observation that justice is given according to values or appropriateness that are not the same.

\section{Bibliography}

Almubarok F, 'Keadilan Dalam Perspektif Islam’ (2018) 1 Jurnal Istighna.

Aristotle, Nicomachean Ethics (William David Ross tr, Batoche Books 1999).

Asshiddiqie J, Konstitusi Keadilan Sosial (PT Kompas Media Nusantara 2018).

Chroust A-H and Osborn DL, 'Aristotle's Conception of Justice' (1942) 17 Notre Dame Law Review.

Dedihasriadi LO and Nurcahyo E, 'Pancasila Sebagai Volkgeist: Pedoman Penegak Hukum Dalam Mewujudkan Integritas Diri Dan Keadilan’ (2020) 9 Jurnal Magister Hukum Udayana <https://doi.org/10.24843/JMHU.2020.v09.i01. p10>.

Djumhana M and Djubaedillah R, Hak Milik Intelektual: Sejarah, Teori, Dan Praktiknya Di Indonesia (Citra Aditya Bakti 2014).

Hidayah K, Hukum Hak Kekayaan Intelektual (Setara Press 2017).

Hidayah K, Hukum HKI Di Indonesia: Kajian Undang-Undang Dan Integrasi Islam (UIN-Maliki Press 2012).

Kamus Besar Bahasa Indonesia, 'Keadilan' $<$ https://kbbi.web.id/keadilan $>$ accessed 20 June 2020.

Krisnayuda B, Pancasila Dan Undang-Undang (Kencana Prenada 2017).

Mashdurohatun A and Mansyur MA, 'Identifikasi Fair Dealing/Fair Use Hak Cipta Atas Buku Dalam Pengembangan IPTEK Pada Pendidikan Tinggi Di Jawa Tengah' (2015) 4 Yustisia $522<$ https://doi.org/10.20961/yustisia.v4i3.8682>.

Nasution MSA and others, Hukum Dalam Pendekatan Filsafat (Kencana 2016).

Parhiana IW, Pengantar Hukum Internasional (Mandar Maju 1990).

Purba AZU, Hak Kekayaan Intelektual Pasca TRIPs (Alumni 2011). 
Rawls J, A Theory of Justice. Revised Edition (Harvard U Press 1999).

Riswandi BA and Mahmashani S, Dinamika Hak Kekayaan Intelektual Dalam Masyarakat Kreatif (Total Media 2009).

Santoso MA, Hukum, Moral Dan Keadilan: Sebuah Kajian Filsafat Hukum (Kencana Prenada Media Group 2012).

Simon Fraser University, 'What Is Fair Dealing and How Does It Relate to Copyright?' $<$ www.lib.sfu.ca/help/academic-integrity/copyright/fair-dealing $>$.

HOW TO CITE: Sigit Nugroho, Derita Praptirahayu and Mieke Yustia Ayu Ratna Sari, 'Fairness in Fair Dealing on Industrial Design Protection' (2021) 36 Yuridika. 